\title{
ARTISTIC AND CREATIVE DEVELOPMENT OF THE JUNIER SCHOOL AGE PUPILS BY MEANS OF ARTS INTEGRATION
}

\section{Olena Ivanenko}

PhD in Pedagoic Sciences, Acting Head of the Department of Humanitarian Disciplines; ORCID: 0000-0003-2785-7728; e-mail: elen-ivanenko@ukr.net

Municipal Institution of Higher Education "Kyiv Academy of Arts", Kyiv, Ukraine

\section{Abstract}

At the present stage of the modernization of the education system in Ukraine, the problem of the creative person formation and his or her ability to artistic and creative activity is one of the main issues in the modern artistic pedagogics of the present. The relevant task is to provide conditions for the artistic and creative development of the every child personality of the junior school age, which contributes to their harmonious and comprehensive development at the artistic educational institutions.

These tasks require updating of artistic concepts and paradigms in the field of artistic and creative education of primary school students. The aggravation of the contradiction between the need of specialized artistic educational institutions in optimizing the creative development of this age children and the insufficient level of methodological providing of the educational process determine the relevance of this analysis.

As it is in the process of artistic and creative activity of the junior school age children, an interest in different types of art develops, and in future love and an inexhaustible desire to engage in certain of them appear, therefore, the success and effectiveness of such development in art schools totally depends on the professionalism and competence of a teacher. Only the teacher in the process of studying is able to create such conditions that will facilitate the acquisition of grades 1-4 pupils of the basic skills of artistic and creative activity and children will be able to remember and recognize works of different kinds of art, to be excited about them, to admire about the content of works, the beauty of their forms and images.

The purpose of this study is to substantiate the basic conditions for teachers of artistic educational institutions regarding the effectiveness of artistic and creative development in the process of studying through the integration of arts. The methodological basis of the article was the generaladectic principles (connection with the surrounding reality, systematic and sequential learning, and an individual approach to the children development of elementary school age), as well as the principles of artistic and creative development of grades 1-4 pupils in art schools, with the specifics of artistic activity various types: encouraging children to discover creative potential in the process of studying various arts; application in the process of integration of art as a means of artistic and creative development of children 
of junior school age; enriching the aesthetic experience of students, as well as the direction of artistic and creative development in understanding the artistic image by mastering the means of artistic expressiveness of various types of art.

Many pedagogical studies have proved that it is the elementary school period that is favorable for the development of the child's creative personality in the process of artistic and creative activity, and this very age contributes to its comprehensive cognitive development. Since pupils of junior school age have high cognitive activity and psychological readiness for artistic and creative activity, they are quite easy to learn and can absorb a large amount of information on different types of art.

Application of integration in the process of studies in art schools with children of junior school age, above all, will allow: to apply an individual approach to each child; to achieve integrity in the pedagogical process; to implement new methods and techniques of artistic and creative education, as well as to fully involve of pupils of grades 1-4 in art schools, by participating in various artistic and creative activities. Indeed, hence to the integration of the arts there is: first, the approach of children to artistic knowledge not only through reason, but also through feelings and emotions; second, the disclosure of the inner world of children of junior school age and their maximum rapprochement with the teacher.

Conclusions The use of artistic integration in classes at artistic educational institutions contributes to a deeper assimilation of pupils of the junior school age of artistic culture and artistic heritage, the development of cognitive interest, and through the development of creative abilities and acquired knowledge, skills and abilities, helps to reveal their artistic and creative potential in the process of participation in various types of artistic and creative activity.

Keywords: artistic and creative activity; artistic and creative development; types of art; integration of arts

\section{Introduction}

One of the important problems of contemporary art pedagogics is the development of a system of organizational forms and advanced means of developing the of a pupil of junior school age creativity on the basis of identifying his or her natural instincts and potential in the process of "... harmonious development of all abilities of the child. Listening to music, songs should be changed by reading poems, drawing, modeling. Because no one knows what kind of human activity can show the special talent given by nature to this particular child, he or she must test the maximum of classes in order to determine its purpose over time ..." (Lesgaft, 1988, p.176).

The desire to engage in artistic and creative activity, which influences the comprehensive development of the junior school age pupil personality, is formed during the mastering of such varieties as musical, visual, theatrical and choreographic. Each of these varieties has its own content, which reveals the essence of artistic activity, and at the same time, these activities are aimed at the artistic and creative development of children of junior school age, in the process of creating opportunities for manifestation of their creative potential and abilities. 
Since the child from the very beginning of his or her development is capable of various types of artistic and creative activity, the application of the integration of arts allows the pupils of the junior class to fully acquire systemic artistic and aesthetic knowledge and skills, to form clear creative beliefs and artistic interests of a holistic aesthetic orientation. In the future, in the learning process in the school of arts, this will enable the creation of comfortable conditions for the comprehensive artistic and creative development of elementary school students.

\section{Analysis of recent researches and publications}

According to many philosophers (M. Berdyayev, V. Solovyov, L. Tolstoy), the process of artistic and creative development of a person is very similar to the search for meaning of life and the creation of a model of one's own destiny. In his research, V. Andreev emphasized that the creative development of the individual is a synthesis of abilities for a purposeful artistic activity, which is of great importance to the individual, that maximizing his creative potential (Andreev, 1988, p.113).

Modern pedagogical science and in the whole complex of adjacent humanities and social sciences consider the problem of development of creative abilities and opportunities of a person, aspiration to artistic and creative activity in the interests of itself and society as a whole as one of the key and decisive. Therefore, on its solution, the efforts of many scholars from different fields of knowledge, pedagogues and practitioners such as N. Anishchenko, N.Vetlugina, S.Sisoyeva, T. Shevchuk are concentrated.

According to N. Babikin, Y. Kulyutkina, S. Stepanova and others, the development of creative thinking and creative abilities is impossible without the assimilation of the cultural and historical experience gained by humanity, the leading base of which is art. Direct contact with art itself does not lead to its true awareness - appropriate preparation for the perception, understanding and evaluation of the work of art is required. 0 . Leontiev emphasizes the significance of this ability to perceive the work of art as a manifestation of the spiritual activity of a man and the need for its development in the person, considering the specificity of artistic education. "Very often," he writes, "we imagine that it is enough to put a person in front of a picture or put it in a theater hall to understand and realized adequately and immediately what he has seen. This is obvious misconception. Like all kinds of communication, communication with art must be taught specially" (Leontiev, 1983, p.67).

O. Burov, O. Leontiev, O. Melik-Pashaev, B. Nemenenskiy emphasize that the perception of works of art is carried out not in the form of passive transmission of feelings and mood, but as an active activity of the person who perceives from the own consideration of prognostic ideas about beautiful and flawless.

As it is in the process of artistic and creative activity in children of junior school age, interest in different types of art develops, and in the future, love and an inexhaustible desire to engage in certain of them appear, therefore, the success and effectiveness of such development in art schools totally depends on the professionalism and competence of the teacher. Only a teacher in the process of studying is able to create such conditions that will facilitate the acquisition of pupils of grades 1-4 of the basic skills of artistic 
and creative activity and through which children will be able to remember and recognize works of different kinds of art, to rejoice at them, to worry about the content of works, the beauty of their form and images.

\section{The purpose of the article}

The purpose of the study is to substantiate the basic conditions for teachers of artistic educational institutions regarding the effectiveness of artistic and creative development in the process of studying through the integration of arts. The methodological basis of the article was the generaladectic principles (connection with the surrounding reality, systematic and sequential learning, and an individual approach to the development of children of elementary school age), as well as the principles of artistic and creative development of pupils of grades 1-4 in art schools, with the specifics of various types of artistic activity: encouraging children to discover creative potential in the process of studying various arts; application in the process of integration of art as a means of artistic and creative development of children of junior school age; enriching the aesthetic experience of students, as well as the direction of artistic and creative development in understanding the artistic image by mastering the means of artistic expressiveness of various types of art.

\section{Presentation of the main material}

In the process of artistic and creative activity of pupils of grades 1-4, close interconnection and interaction between different types of arts is envisaged, which contributes to raising the students' interest in active artistic and cognitive activity, and also expands the possibilities for the manifestation of creative abilities. One of the important factors in improving the effectiveness of artistic and creative development of this age students is the process of art integration. It is through the interaction of arts, which becomes of great importance in modern education, new opportunities and effective ways of artistic realization of reality can arise, which provides for the disclosure of the child's creative abilities and contributes to its artistic and creative development.

In today's artistic education, the idea of the most comprehensive use of various types of art for the effective artistic and creative development of primary school children becomes very relevant, while the encourage to interaction has already been laid in the art itself, namely, in its functional and genetic ties; and it is based on the general art like nature of varieties of art, united by common features, such as: artistic idea, artistic image and artistic language. The problem of the use of the interaction of arts can be considered not only through the common, but also through the opposite, whereas such interaction is based precisely on the fact that each kind of art has certain specific features that are not present in others.

Every art has its own peculiarities of influence on the child and the means of artistic expressiveness, which are characteristic only for this variety (color - for fine art, melody - for musical, movement - for choreographic, word for theatrical).

"The basis of all varieties of art is the reality, which different types of art reflect their language - the language of sounds, colors, and plasticity," Sh. Amonashvili emphasized. 
"If we were able to create such scales, which could weigh up the types of art, then I am sure that none of the types of art would be more weighty than the other. All of them are the branches of one tree. And if I want to give the children a full-fledged artistic education, then I am obliged to help to see this tree with its crown, and help to bring them closer to its top" (Amonashvili, 1988, p. 100).

All varieties of art are interconnected with each other, by means of existence and by their development, and thereby they form a certain system that characterizes certain connections and relations that are formed between them. Each type of art has a certain pictorial-expressive range, and, in its turn, reflects the diversity of its own specific capabilities, which determine the nature of the impact on the child personality of preschool age. Thus, a separate kind of art that has some influence on the child, necessarily captures not only the various aspects of the psyche, but also influences the sphere of feelings.

In the study of N.Grigoriev it is possible to find the opinion that the influence of the complex of types of art is transformed in consciousness due to the complex prism of the psychological properties and qualities of the personality of the child, which mobilizes feelings, thoughts, imagination, intelligence, all life experience, because any influence of a phenomenon is refracted due to the internal properties of the phenomenon in interaction with which it acts (Grigorev, \& Shevchenko, 1980).

If one type of artistic and creative activity deeply touched the soul world of a child of junior school age, then it will definitely seek to show its emotional mood in another. In the process of studying art by students in elementary school there is a feeling of their own manifestation, because it is an artistic and creative activity that corresponds to the very nature of the child, and also provides aesthetic pleasure that motivates and encourages it for artistic and creative activity.

In classes with the use of artistic integration, all types of art must be involved, because only in their combination one can emphasize the specifics of each of them. This will enable primary school students to gain experience not only in a certain type of art, but also allow them to comprehend all forms of different types of artistic activities in terms of their age perception.

Integration of different types of art in artistic and creative development of children of elementary school age is possible only because certain varieties of art (fine arts, musical, choreographic, etc.), which reflect the same object of the surrounding reality, but from different sides, various, inherent only to a certain the form of art, means of expression, which, by integrating, create holistic images in the representation of children and act as an effective factor for displaying in the students of art schools of creative abilities in various artistic and creative activities.

It is known that the game remains the dominant form of activity for junior schoolchildren, so children easily include art in their lives. According to P. Pisarevskiy, "this manifests itself both in the use of art and in its creation. Discussing the conditions of the game, children also naturally, harmoniously, without thinking, accept the convention of art" (Pisarevskiy, 1987, p. 52).

The urgency of the application of artistic integration is determined not only by the artistic, but also by the social and aesthetic needs of the individual. The aesthetic phenomenon of reality, due to the integration of arts, has advantages over the 
possibilities of certain types of art. By combining artistic means of various types of art into a single entity, the teacher can achieve results in a more optimal term. Each art is distinguished by the peculiarity of the means of expressiveness. Musical art reproduces visual images, the visual arts adds to the auditory, theatrical art combines elements of others and enjoys all of them. The combination of different types of art into a single whole in artistic and creative activity contributes to the complementarity of means of expressiveness, which, in its turn, deepens the cognitive interest in art and creates a certain emotional atmosphere without which the act of perception is impossible" (Zhukov, 2017).

In order for the effectiveness of artistic and creative development of junior school age children to be high it is necessary to create the pedagogical conditions under which we understand the circumstances of the educational process that take place in classes at art schools and contribute to its effectiveness. Therefore, one of the conditions is to make a creative, relaxed atmosphere in classes of various arts, devoid of authoritarian direction of the teacher, in order to allow children to express their creative abilities and potential freely.

To realize this pedagogical condition in the process of studying on the principles of arts integration, first of all, it is necessary to capture the teacher's own pedagogical work. His professional skills must be manifested not only in the way he or she speaks, but also how the teacher shows works of art to junior school age children in order to capture and lead them. Only in the relaxed atmosphere of emotional uplift and interest of grades 1-4 pupils the efficiency of classes increases and conditions for artistic and creative development are created.

The next condition for improving the effectiveness of artistic and creative development of junior school age pupils in the process of various arts studying is the use of accessible and at the same time high-quality artistic material in order to activate such an important component of artistic and creative development of children of this age as the presence of cognitive interest.

The requirement for the repertoire to be accessible is generally considered in two aspects: the availability of content of works of art and the availability for reproduction by the 1-4 grades pupils. The latter position is determined by the age-old possibilities of children, their particular life and artistic experience. And the availability of content should not be seen as the use of exclusively software and image images that are close enough to children of this age (nature, game, images of animals, etc.) and give resistance to the external object signs of the image, and above all, this requirement is considered as the correspondence of the emotional content of the work feeling what children of this age are able to experience at the moment. Thus, in this aspect, it is very important to enrich the emotional experience of a junior school age child, namely, the ability to empathize with the feelings expressed in works of art.

And the last pedagogical condition for increasing the efficiency of artistic and creative development of junior school age children is the introduction of problemsolving situations in the process of mastering the artistic material.

In order for the pupils of 1-4 grades to master the high-educational material in the best possible way, and education and training to be of a really creative nature, a necessary condition in the process of studying, on the basis of the integration of arts, is 
the introduction of problem-solving situations. It is necessary to create such situations that will contribute to a self-search by students of this age for answers to questions and means of artistic activity.

It is clear that in order to achieve the teacher's educational goal it is easier to provide immediately the necessary knowledge and show the means of action, but the introduction of problem-searching situations, though it requires the teacher to spend quite a lot of time and effort, but nevertheless it gives the student an opportunity due to his knowledge, independently to find the answers to the questions raised, because he or she learns to think independently and thus begins to believe in his or her own strength, and this is very valuable for the implementation of artistic and creative development of junior school age children.

Primary class students can not only reproduce, but also independently create their own works in various artistic activities. In musical activity, children of this age during listening can orient in the genres of musical works with their characteristic features, improvise musical melodies, as well as perform songs without musical accompaniment or pick up a simple melody on musical instruments, as well as control the rhythm of their own performance, that is, to notice the wrong intonations in singing or playing musical instruments.

In the choreographic activity they learn to express and clearly their movements, to transmit a characteristic image, to combine already known dance moves. On their own initiative, primary school students dance, while singing a fictional melody and at the same time clearly repeating the rhythm of a familiar dance. Students feel and easily emphasize the change of parts of the work and changing the corresponding movements. Repeating an action, the child of this age easily transforms it, and then repeats the option that she likes more. Pupils of the junior school age perfectly improvise and create their own dance compositions, as well as demonstrate the ability to independently assess their own choreographic performance.

In the visual activity of the child develops the ability to notice the means of expressiveness in the works of art, to display previously acquired knowledge to solve new creative tasks, to reflect independently on the idea of the future work. The teacher helps children to acquire the ability to independently monitor, perceive, and think, for which the questions formulated by him contribute to thinking before answering, and also teaches children to notice the characteristic features of objects, to analyze the form, to determine the similar and opposite, to see the richness of colors and forms of the surrounding world. Pupils of the junior school age are able to display independently various compositional structures in the drawing or sculpture, realize their plan graphically or in color and convey the expressive moments of the imaginary character.

Consequently, the involvement of children of junior school age in various types of artistic and creative activity in art schools on an integrated basis contributes to the expression of their creative manifestations when displaying a certain artistic image, the use of acquired cognitive skills in the creation of their own works in various art forms, and, most importantly, makes it possible transfer their own emotional mood from the heard or seen.

Application of integration of art in the process of artistic and creative development allows to cover the diversity of the surrounding world, to increase the aesthetic influence 
of artistic images on the personality of junior school age children, since it is very difficult to solve this problem with one type of art, and the very combination of arts can develop creative potential and creative abilities. Primary school students through the use of the method of creative tasks and creative games, the purpose of which is to develop aesthetic perception, associative thinking, artistic creative abilities of children of this age, as well as to educate the aesthetic attitude to different types of art.

\section{Conclusions}

Due to the introduction of artistic integration there are some important aspects : first, the approach of children to artistic knowledge not only through mental activity, but also through feelings and emotions; second, the disclosure of the inner world of children of junior school age and their maximum rapprochement with the teacher. After all, the use of an integrative approach at classes in art schools with children of junior school age will allow them to be fully involved in the world of art through participation in various artistic and creative activities, as well as to achieve integrity in the pedagogical process and create opportunities for the effective realization of new methods and receptions of artistic and creative learning through an individual approach to each student.

\section{References}

Amonashvili, Sh.A. (1988). Zdravstvuyte, deti! [Hello, children!] (2nd ed.) Moscow: Prosveshchenie [in Russian].

Andreev, V.I. (1988). Dialektika vospitaniya i samovospitaniya tvorcheskoy lichnosti: osnovy pedagogiki tvorchestva [Dialectics of education and self-education of a creative personality: the basics of the pedagogy of creativity]. Kazan: Kazanskii University [in Russian].

Grigorev, N.D., \& Shevchenko, G.P. (1988). Problemy vzaimodeistviia iskusstv v sisteme esteticheskogo vospitaniia [Problems of the interaction of arts in the system of aesthetic education]. In Estetichyeskoye vospitaniye $v$ shkolye. Voprosy sisytemnogo pokhoda [Aesthetic education in school. System hike issues] (pp. 61-67). Moscow: Prosveshchenie [in Russian].

Lesgaft, P.F. (1990). Izbrannye pedagogicheskie sochineniia [Selected pedagogical writings]. Moscow: Pedagogika [in Russian].

Pisarevskiy P.S., \& Petrova lu.N. (1987). Problemy esteticheskogo razvitiia lichnosti shkolnika [Problems of aesthetic development of the student's personality]. Moscow: Pedagogika [in Russian].

Zhukov, V. (2017). Sut intehrovanoho navchannia shkoliariv predmetiv mystetskoho tsyklu [The essence of the integrated education of students of arts subjects]. Pedahohika ta psykholohiia, 57, 54-62. doi: 10.5281/zenodo.843219 [in Ukrainian].

Zhuravlova, L., \& Ipkaieva, K. (2019). Formuvannia tvorchykh zdibnostei starshykh doshkilnykiv zasobamy intehratsii riznykh vydiv khudozhnoi tvorchoi diialnosti [Formation of creative abilities of senior preschool children by means of integration of various types of artistic and creative activity]. Molod i rynok, 1 (168), 17-22. doi: 10.24919/2308-4634.2019.158313 [in Ukrainian]. 


\title{
ХУДОЖНЬО-ТВОРЧИЙ РОЗВИТОК УЧНІВ МОЛОДШОГО ШКІЛЬНОГО ВІКУ ЗАСОБОМ ІНТЕГРАЦІЇ МИСТЕЦТВ
}

\author{
Олена Іваненко
}

кандидат педагогічних наук; ORCID: 0000-0003-2785-7728; e-mail: elen-ivanenko@ukr.net МЗВо «Київська Академія мистецтв», Київ, Україна

\section{Анотація}

На сучасному етапі модернізації системи освіти в Україні проблема формування творчої особистості та її здатності до художньо-творчої діяльності посідає одне з чільних місць у мистецькій педагогіці сьогодення. Актуальним завданням $є$ забезпечення умов для художньо-творчого розвитку особистості кожної дитини молодшого шкільного віку, що сприяє їі гармонійному та всебічному розвитку в умовах мистецьких навчальних закладів.

Ці завдання потребують оновлення мистецьких концепцій та парадигм у галузі художньо-творчого навчання учнів початкових класів, а загострення суперечності між потребою спеціалізованих мистецьких навчальних закладів в оптимізації творчого розвитку дітей даного віку та недостатнім рівнем методичного забезпечення навчального процесу зумовлює актуальність даного дослідження.

Оскільки саме в процесі художньо-творчої діяльності у дітей молодшого шкільного віку розвивається інтерес до різних видів мистецтва, а надалі й любов та невичерпне бажання займатися певним з них, тому успіх й ефективність такого розвиткув мистецьких навчальних закладах повністю залежить від професіоналізму та компетентності викладача. Тільки педагог в процесі занять здатний створити такі умови, що сприятимуть набуттю учнями 1-4 класів основних навичок художньо-творчої діяльності й завдяки яким діти матимуть змогу запам'ятовувати та впізнавати твори різних видів мистецтва, радіти їм, перейматися змістом творів, красою їх форми та образів.

Мета дослідження - обґрунтування основних умов для педагогів мистецьких навчальних закладів щодо ефективності художньо-творчого розвитку в процесі занять засобами інтеграції мистецтв. У методологічну основу дослідження були покладені загальнодидактичні принципи (зв'язок з навколишньою дійсністю, системність та послідовність навчання та індивідуальний підхід до розвитку дітей молодшого шкільного віку), а також принципи художньо-творчого розвитку учнів 1-4 класів у школах мистецтв, які пов'язані зі специфікою різних видів мистецької діяльності: спонукання дітей до розкриття творчого потенціалу в процесі занять різними видами мистецтв; застосування в процесі занять інтеграції мистецтв як засобу художньо-творчого розвитку дітей молодшого шкільного віку; збагачення естетичного досвіду учнів, а також спрямованість художньотворчого розвитку щодо осягнення художнього образу шляхом засвоєння засобів художньої виразності різних видів мистецтва.

У багатьох педагогічних дослідженнях було доведено, що саме початковий шкільний період є сприятливим щодо розвитку творчої особистості дитини в процесі художньотворчої діяльності, і саме цей вік сприяє їі всебічному пізнавальному розвитку. Оскільки учні молодшого шкільного віку виявляють високу пізнавальну активність та психологічну готовність до художньо-творчої діяльності, вони досить легко піддаються навчанню і можуть засвоїти великий обсяг інформації з різних видів мистецтва. 
Застосування інтеграції в процесі занять в школах мистецтв з дітьми молодшого шкільного віку, найперше, дозволить: застосувати індивідуальний підхід до кожної дитини; досягнути цілісності в педагогічному процесі; реалізувати нові методи та прийоми художньотворчого навчання, а також, в повній мірі, залучити учнів 1-4 класів до світу мистецтва, шляхом участі в різних видах художньо-творчої діяльності. Адже з впровадженням інтеграції мистецтв відбувається: по-перше, наближення дітей до мистецьких знань не тільки через розум, а й через відчуття та емоції; по-друге, розкриття внутрішнього світу дітей молодшого шкільного віку та їх максимальне зближення з педагогом.

Висновки. Застосування художньої інтеграції на заняттях в мистецьких навчальних закладах сприяє глибокому засвоєнню учнями молодшого шкільного віку художньої культури та мистецької спадщини, розвитку пізнавального інтересу, а завдяки розвитку творчих здібностей та набутих знань, умінь й навичок, допомагає розкрити їх художньотворчий потенціал в процесі участі в різних видах художньо-творчої діяльності.

Ключові слова: художньо-творча діяльність; художньо-творчий розвиток; види мистецтва; інтеграція мистецтв

\section{ХУДОЖЕСТВЕННО-ТВОРЧЕСКОЕ РАЗВИТИЕ УЧЕНИКОВ МЛАДШЕГО ШКОЛЬНОГО ВОЗРАСТА СРЕДСТВОМ ИНТЕГРАЦИИ ИСКУССТВ}

\section{Елена Иваненко}

кандидат педагогических наук; ORCID: 0000-0003-2785-7728; e-mail: elen-ivanenko@ukr.net МувО «Киевская Академия искусств», Киев, Украина

\section{Аннотация}

На современном этапе модернизации системы образования в Украине проблема формирования творческой личности и её способности к художественно-творческой деятельности занимает одно из ведущих мест в художественной педагогике настоящего времени. Актуальной задачей является обеспечение условий для художественнотворческого развития личности каждого ребенка младшего школьного возраста, что способствует её гармоничному и всестороннему развитию в условиях учебных заведений в области искусств.

Эти задачи требуют обновления художественных концепций и парадигм в сфере художественно-творческого обучения учащихся начальных классов, а обострение противоречия между потребностью специализированных учебных заведений в области искусств в оптимизации творческого развития детей данного возраста и недостаточным уровнем методического обеспечения учебного процесса, обуславливает актуальность данного исследования.

Поскольку, именно в процессе художественно-творческой деятельности у детей младшего школьного возраста развивается интерес к различным видам искусства, а в дальнейшем и любовь, и неисчерпаемое желание заниматься определенным из них, поэтому успех и эффективность такого развития в художественных учебных заведениях полностью зависит от профессионализма и компетентности преподавателя. Только педагог 
в процессе занятий способен создать такие условия, способствующие приобретению учащимися 1-4 классов основных навыков художественно-творческой деятельности и, благодаря которым, дети смогут запоминать и узнавать произведения разных видов искусства, радоваться им, заниматься содержанием произведений, красотой их формы и образов.

Цель исследования - обоснование основных условий для педагогов специализированных учебных заведений в области искусств по эффективности художественно-творческого развития в процессе занятий средствами интеграции искусств. Методологическую основу исследования составляют общедидактические принципы (связь с окружающей действительностью, системность и последовательность обучения и индивидуальный подход к развитию детей младшего школьного возраста), а также принципы художественно-творческого развития учащихся 1-4 классов в школах искусств, которые связаны со спецификой различных видов художественной деятельности: побуждение детей к раскрытию творческого потенциала в процессе занятий различными видами искусств; применение в процессе занятий интеграции искусств как средства художественно-творческого развития детей младшего школьного возраста; обогащение эстетического опыта учащихся, а также направленность художественнотворческого развития по постижению художественного образа путем усвоения средств выразительности различных видов искусства.

Во многих педагогических исследованиях было доказано, что именно начальный школьный период является благоприятным в развитии личности ребенка в процессе художественно-творческой деятельности, и именно этот возраст способствует его всестороннему познавательному развитию. Поскольку ученики младшего школьного возраста проявляют высокую познавательную активность и психологическую готовность к художественно-творческой деятельности, они достаточно легко поддаются обучению и могут усвоить большой объем информации по различным видам искусства.

Применение интеграции в процессе занятий в школах искусств с детьми младшего школьного возраста, прежде всего, позволит: применить индивидуальный подход к каждому ребенку; достичь целостности в педагогическом процессе; реализовать новые методы и приемы художественно-творческого обучения, а также, в полной мере, привлечь учащихся 1-4 классов к миру искусства, путем участию в различных видах художественнотворческой деятельности. Ведь вследствие внедрения интеграции искусств происходит: во-первых, приближение детей к художественным знаниям не только через разум, но и через чувства и эмоции; во-вторых, раскрытие внутреннего мира детей младшего школьного возраста и их максимальное сближение с педагогом.

Выводы. Применение художественной интеграции на занятиях в творческих учебных заведениях способствует более глубокому усвоению учащимися младшего школьного возрастахудожественной культурыихудожественногонаследия, развитиюпознавательного интереса, а благодаря развитию творческих способностей и приобретенных знаний, умений и навыков, помогает раскрыть их художественно-творческий потенциал в процессе участия в различных видах художественно-творческой деятельности.

Ключевые слова:художественно-творческая деятельность; художественно-творческое развитие; виды искусств; интеграция искусств. 